\title{
1. Antithesis in Anglo-American administrative common law
}

\section{BACKGROUND}

Administrative law, to use the concept of law developed by the British legal philosopher H.L.A. Hart, ${ }^{1}$ consists of the union of primary rules governing how the administrative state ought to discharge its powers and responsibilities, and secondary rules that empower judges and administrative tribunals to produce and amend primary rules, and resolve disputes between officials and citizens. ${ }^{2}$ It has been hailed as "the hard-working, unglamorous cousin laboring in the shadow of constitutional law," for it embodies not only "formal authorizations" but also "values and principles" that regulate government action; it is "as much concerned with the protection and validation of good administration as it is with controlling abuses of power." Contemporary administrative law exists at the intersection between the state, society, and the economy, ${ }^{6}$ thanks to the mushrooming of the administrative state, the ambit of which now sweeps in all policy domains, from national security, energy, and air and

\section{H.L.A. Hart, The Concept of Law 79 (3d ed. 2012).}

2 Peter Cane, Public Law, in The Concept of Law, 33 Oxford J. Legal Stud. 649, 666 (2013); John S. Bell, Comparative Administrative Law, in The OxFord HandBook of Comparative Law 1261, 1261 (Mathias Reimann \& Reinhard Zimmermann ed., 2006).

3 Tom Ginsburg, Written Constitutions and the Administrative State: On the Constitutional Character of Administrative Law, in Comparative Administrative LAw 60, 60 (Susan Rose-Ackerman et al. eds., 2d ed. 2017).

4 Paul Daly, Administrative Law: Characteristics, Legitimacy, Unity, in THE Unity of Public Law? Doctrinal, Theoretical and Comparative Perspectives 101, 101 (Mark Elliott et al. eds., 2018) ("In brief, the defence [of the legitimacy of modern administrative law] is that judicial review of administrative action is inevitably a value-based enterprise; that the structure of administrative law is provided by the interaction of four values - the rule of law, good administration, democracy and separation of powers.")

5 Stephen Sedley, Lions Under the Throne: Essays on the History of English Public Law 9 (2015).

6 Susan Rose-Ackerman et al., Introduction, in Comparative Administrative LAW 1, 1 (Susan Rose-Ackerman et al. eds., 2d ed. 2017). 
water quality, to civil rights, consumer protection, workplace conditions, and taxation. ${ }^{7}$ In the United States, federal administrative agencies exercise rulemaking, investigative, prosecutorial and adjudicative powers $;{ }^{8}$ are authorized to use both ex ante and ex post regulation; ${ }^{9}$ and routinely decide in their own discretion which areas of citizens' lives merit state intervention. ${ }^{10}$ The sheer quantity of legal rules emanating from it, compared to statutes enacted by the legislature, evidences the administrative state's pervasiveness. In 2015 and 2016 the American agencies filled over 175,000 pages of the Federal Register with 7,263 final rules; compared to the 3,036 pages in the Statutes at Large taken up by the 329 public laws enacted by the United States Congress. ${ }^{11}$ In the very same period, the number of statutory instruments, Britain's answer to America's regulations, totaled 3,301 in contrast to the mere 62 chapters in the United Kingdom Parliament's statute for that session. ${ }^{12}$ The dilemma of checking yet enabling administrative discretion raises a host of issues relating to democratic accountability and legitimacy, and poses a unique challenge to the rule of law. ${ }^{13}$ Judicial review of administrative action, focused predominantly but not exclusively on the legality and the procedural soundness of administrative decision-making, is one of the most important ways of keeping discretion within constitutional bounds in the United Kingdom and the United States. Unlike their Romano-Germanic counterparts, ordinary, generalist courts in the common law world, empowered by the doctrine of precedent, are competent to fashion judicial doctrines of administrative law, also known as "administrative common law," 14 which imposes a rational structure on agency

7 Stephen G. Breyer et al., Administrative Law and Regulatory Policy: Problems, Text, and Cases 1 (8th ed. 2011).

8 Adrian Vermeule, The Constitution of Risk 119 (2014).

9 Richard A. Posner, Economic Analysis of Law 852 (8th ed. 2011).

10 Michael Greenstone, Toward a Culture of Persistent Regulatory Experimentation and Evaluation, in New Perspectives on Regulation 113, 113 (David Moss \& John Cisternino eds., 2009).

11 Christopher J. Walker, Restoring Congress's Role in the Modern Administrative State, 116 Mich. L. Rev. 1101, 1101-02 (2018).

12 John Stanton \& Craig Prescott, Public Law 312 (2018).

13 Christine B. Harrington \& Lief H. Carter, Administrative Law and Politics: CASES AND Comments 2 (5th ed. 2015).

14 Kathryn E. Kovacs, Superstatute Theory and Administrative Common Law, 90 IND. L.J. 1207 (2015); Gillian E. Metzger, Embracing Administrative Common Law, 80 Geo. Wash. L. Rev. 1293 (2012). The term "common law" is used principally in this book to denote legal rules and principles developed by judges in the course of adjudication that are often not strictly required by constitutions and statutes. See Henry P. Monaghan, Constitutional Common Law, 89 HARv. L. Rev. 1, 2 (1975). In other contexts, "common law" has been used variously to refer to a type of legal system descended from English law as opposed to other types of legal system, such as the 
decision-making processes, prioritizing the values of predictability and reasonableness. ${ }^{15}$ In the common law world, administrative law reflects how judges as umpires of the administrative state "translate the theory of the rule of law into controls of bureaucratic power."'16

Positive political theory (PPT), a subfield of political science and economics, has contributed important insights into the empirical and, increasingly, the normative study of administrative law in the United States in the past four decades. ${ }^{17}$ Variously referred to as "positive political theory," "positive political economy," "public choice," and the like, ${ }^{18}$ PPT denotes the analysis of political institutions, decision-making and behavior from the standpoint of microeconomics and its methodological and theoretical assumptions, that is, that policy outcomes emerge from the self-interested choices of utility-maximizing, instrumentally rational political actors who, like market actors, interdependently interact in the absence of perfect information. ${ }^{19}$ PPT specifically focuses on collective action problems in which the interests and preferences of individual decision-makers cannot be easily reconciled and coordinated. Such problems are apt to occur in situations where mobilization and coordination are difficult. ${ }^{20}$ PPT's principal contributions to public law encompass, but are not limited to measuring and predicting, throughout the process, the supply and demand of legislation owing to the influence of special interest groups. ${ }^{21}$ PPT scholars have begun to investigate through an economic lens the political

French civilian law tradition, and a branch of judge-developed law known as the "rules of the common law" as opposed to another branch of principles in judge-developed law called the "rules of equity." See Eric C. Ip, Law and Justice In Hong Kong 12 (3d ed. 2019).

15 Mark Elliott \& Robert Thomas, Public Law 616 (3d ed. 2017); Linda D. Jellum, Mastering Administrative Law 25 (2d ed. 2018).

16 Harrington \& CARTER, supra note 13 , at 26.

17 See Jerry L. Mashaw, Greed, Chaos, and Governance: Using Public Choice to Improve Public Law (1997); Richard A. Posner, The Rise and Fall of Administrative Law, 72 Chi.-Kent L. Rev. 953 (1997); Daniel B. Rodriguez, Administrative Law, in The Oxford Handbook of Law and Politics 340 (Keith E. Whittington et al. eds., 2008); Daniel A. Farber \& Anne Joseph O'Connell, Introduction: A Brief Trajectory of Public Choice and Public Law, in Research Handbook on Public Choice and Public Law 1 (Daniel A. Farber \& Anne Joseph O’Connell eds., 2010).

18 Daniel A. Farber, Public Choice Theory and Legal Institutions, in The Oxford Handbook of Law and Economics: Volume I: Methodology and Concepts 181, 181 (Francesco Parisi ed., 2017).

19 See Dennis Mueller, Public Choice III (2003); Matthew D. McCubbins et al., The Political Economy of Law, in HandBook of LAw AND Economics 21662 (A.M. Polinsky and S. Shavell eds., 2007).

20 Farber, supra note 18, at 183.

21 Daniel A. Farber \& Philip P. Frickey, Foreword: Positive Political Theory in the Nineties, 80 Geo. L.J. 457 (1992). 
forces that influence the content of judicial doctrines in public law. ${ }^{22}$ The high relevance of PPT to administrative law research is reinforced by the fact that its subject matter - the law that regulates the regulator ${ }^{23}$ - overlaps significantly with public economics and public finance, both of which offer normative justifications for state intervention in society as well as explanatory models for governmental delegation and oversight. ${ }^{24}$

Prominent legal scholars Elizabeth Magill and Daniel Ortiz recently predicted that PPT analyses must break down when applied to the administrative law of the United Kingdom, where judicial review of administrative action "has real bite" 25 and "is much more than a rubber stamp." 26 Judicial review in administrative law, according to their interpretation of PPT, is consequential only inside presidential systems like that of the United States, where gridlock between the president and the legislature leaves room for agency malfeasance, and also opportunities for judicial intervention. By contrast, the close alignment of Government and Parliament in Westminster systems "squeezes out" opportunities for agencies to contradict their principals, and with it any space for judicial activism. ${ }^{27}$ This conjecture is convincing in a constitutional law context, but not an administrative law one: the Supreme Court of the United States does invalidate Acts of Congress as unconstitutional, whereas the Appellate Committee of the House of Lords and its successor, the Supreme Court of the United Kingdom, have consistently upheld the doctrine of parliamentary sovereignty. ${ }^{28}$

22 See Rachel K. Hinkle et al., A Positive Theory and Empirical Analysis of Strategic Word Choice in District Court Opinions, 4 J. Legal Analysis 407 (2012); Tonja Jacobi \& Emerson H. Tiller, Legal Doctrine and Political Control, 23 J.L. Econ. \& ORG. 326 (2007).

23 Administrative law is conceptually different from the actual delegated legislation and regulations made by administrative officials: these are categorized as "regulatory law." HARRINGTON \& CARTER, supra note 13, at 25.

24 Susan Rose-Ackerman, Introduction, in Economics of Administrative LaW xiii, xiii (Susan Rose-Ackerman, ed., 2007).

25 M. Elizabeth Magill \& Daniel R. Ortiz, Comparative Positive Political Theory and Empirics, in Comparative Administrative Law 71, 77 (Susan Rose-Ackerman et al. eds., 2 d ed. 2017).

26 Id. at 80.

27 Id. at 74 .

28 In $R v$. Sec'y of State for Transp., ex parte Factortame Ltd. [1991] A.C. 603 and $R$ v. Sec'y of State for Employment, ex parte Equal Opportunities Comm'n [1995] 1 A.C. 1, the Appellate Committee of the House of Lords had asserted the power to "disapply" Acts of Parliament that breach European Union directives. However, this case, as with similar ones, merely reiterated the supremacy of European Union law over relevant aspects of UK domestic law, rather than applied domestic constitutional principles to gauge the merits of primary legislation. Furthermore, this decision has not triggered 
Contrary to the Magill-Ortiz criticism, the accepted view among PPT scholars is that the judiciary's primary function in administrative law is to assume routine oversight tasks like monitoring lower-level government agents, rather than deciding fundamental political and ethical values as in constitutional adjudication. ${ }^{29}$ The PPT of administrative law is about how agency costs are manipulated and reduced. There is no conclusive evidence that administrative officials in presidential systems shirk more than their counterparts in parliamentary ones. Regardless of their shared origins in history, administrative law jurisprudence on both sides of the "common law Atlantic" part company in too important ways to be ignored. Most notably, the United Kingdom and the United States have arrived at "exactly opposite" doctrines of judicial review respecting issues of statutory interpretation and policy discretion. ${ }^{30}$ Through much of the twentieth century, judicial review of administrative action was "little more than perfunctory" in the United Kingdom, ${ }^{31}$ and "moribund" in the United States. ${ }^{32}$ A glaring example of judicial minimalism is the Lords' decision in Liversidge v. Anderson, ${ }^{33}$ which affirmed an administrative power to detain any person whom the Home Secretary had nothing more than "reasonable cause to believe" was hostile, unless it is shown that he actually knew that no reasonable cause underpinned his belief. ${ }^{34}$ This attitude changed, however, in the $1960 \mathrm{~s}$, when administrative common law underwent a "revolution" 35 which "transformed [it] exponentially," ${ }^{36}$ ushering-in a period of "unparalleled

in England and Wales any wave of judicial review of legislation on European Union law grounds. See Brice Dickson, Judicial Activism in the House of Lords 1995-2007, in Judicial Activism in Common Law Supreme Courts 363 (Brice Dickson ed., 2007).

29 See Nuno Garoupa \& Tom Ginsburg, Hybrid Judicial Career Structures: Reputation Versus Legal Tradition, 3 J. Legal Analysis 431 (2011); William Bishop, A Theory of Administrative Law, XIX J. Legal Stud. 489 (1990).

30 Notice that, as analytical categories, questions of law and questions of policy and fact are not mutually exclusive. John Dickinson, Administrative Justice And THE Supremacy of Law 55 (1927) ("errors of law grow downward into roots of fact, and matters of fact reach upward without a break, into mattes of law.") See Robert C. Dolehide, A Comparative "Hard Look" at Chevron: What the United Kingdom and Australia Reveal About American Administrative Law, 99 Tex. L. Rev. 1281 (2010).

31 Stanley A. De Smith, Judicial Review of Administrative Action 28 (3d ed. 1973).

32 Martin Shapiro, Courts: A Comparative and Political Analysis 118 (1986).

33 Liversidge v. Anderson [1942] A.C. 206.

34 Harry Woolf et al., De Smith's Judicial Review 240-250 (8th ed. 2018).

35 David Williams, Law and Administrative Discretion, 2 InD. J. Global Legal STUD. 192 (1994).

36 Michael Supperstone \& Lynne Knapman, Administrative Court Practice 1 (2008). 
judicial creativity" when "the range of bodies subject to judicial review [was] much widened." 37 This did not happen overnight, but the "innovative" jurisprudence of the Law Lords "set the tone for all that was to follow." "38

This change was not caused by structural factors such as a change of personnel in the English judiciary, but by the agency of the same Oxbridge-educated, Caucasian, male judges, who had increasingly perceived with great anxiety that the administrative and regulatory state was expanding its encroachments on individual liberties. They reacted by expanding their powers of judicial review correspondingly, ${ }^{39}$ an almost entirely "judge-driven phenomenon." 40 Strong personalities such as Lords Reid (1890-1975), Diplock (1907-1985), Wilberforce (1907-2003), and Scarman (1911-2004) were committed to the belief that the rights enjoyed by subjects of British democracy were so important as to warrant judicial protection even to the point of reversing the decisions of elected ministers, if necessary. ${ }^{41}$ In Padfield $v$. Minister of Agriculture, Fisheries, and Food, ${ }^{42}$ the Law Lords rejected any grant of unfettered discretion to administrative bodies: "the use of that adjective [unfettered], even in an Act of Parliament, can do nothing to unfetter the control which the judiciary have over the executive, namely, that in exercising their powers the latter must act lawfully and that it is a matter to be determined by looking at the Act and its scope and object in conferring a discretion upon the minister rather than by the use of adjectives." 43 The ensuing case of Anisminic v. Foreign Comp. Comm ' $n^{44}$ became authority for the rule that "any error of law makes a decision a nullity," and the byword that there is no administrative error "which cannot be dressed up as an error of law." 45 Lord Reid's list of administrative errors

37 Christopher F. Forsyth \& Linda Whittle, Judicial Creativity and Judicial Legitimacy in Administrative Law, 8 CANTA. L. Rev. 453 (2002).

38 Michael J. Beloff, The End of the Twentieth Century: The House of Lords 1982-2000, in Louis Blom-Cooper et al., eds, The Judicial House of Lords, 1876-2009 231 (2009).

39 Philip Norton, The Judiciary, in Politics UK 436, 446 (Bill Jones \& Philip Norton eds., 8th ed. 2014).

40 Anthony King, Who Governs Britain? 273 (2015).

Id.

Padfield v. Minister of Agriculture, Fisheries, and Food [1968] A.C. 997, 1030.

Id., at 1060 .

44 Anisminic v. Foreign Comp. Comm'n [1969] 2 A.C. 147 [hereinafter Anisminic].

45 David Feldman, Anisminic Ltd v. Foreign Compensation Commission [1968]:

In Perspective, in Landmark Cases in Public Law 93 (Satvinder Juss \& Maurice Sunkin eds., 2017). 
that could be dressed up into nullifiable legal errors has proved enduring and influential: 46

[An administrative authority] may in perfect good faith have misconstrued the provisions giving it power to act so that it failed to deal with the question remitted to it and decided some question which was not remitted to it. It may have refused to take into account something which it was required to take into account. Or it may have based its decision on some matter which, under the provisions setting it up, it had no right to take into account. I do not intend this list to be exhaustive.

In O’Reilly v. Mackman, ${ }^{47}$ Lord Diplock teased out its implications:

[Anisminic] liberated English public law from the fetters that the courts had theretofore imposed upon themselves so far as determination of inferior courts and statutory tribunals were concerned, by drawing esoteric distinctions between errors of law committed by such tribunals that went to their jurisdiction, and errors of law committed by them within their jurisdiction. The break-through that the Anisminic case made was with recognition by the majority of this House that if a tribunal whose jurisdiction was limited by statute or subordinate legislation mistook the law applicable to the facts as it had found them, it must have asked itself the wrong question, i.e., one into which it was not empowered to inquire and so had no jurisdiction to determine.

In consequence, public administrators' awareness of the consequentialness of judicial review was heightened, as indicated by a Thatcher Government pamphlet titled "The Judge Over Your Shoulder," or JOYS as it was sarcastically known inside government circles; designed to provide junior officials with guidance on the practical operation of administrative law principles. ${ }^{48}$ JOYS has since gone through multiple editions, and in fact, despite disclaimers to the contrary, was published to educate public administrators how to preempt or survive judicial review. ${ }^{49}$

Between the 1940s and 1960s, the United States federal courts had acquiesced in the mushrooming post-New Deal administrative state, by permitting the doctrine of non-delegation to be honored more in the breach than in the observance. $^{50}$ This had been preceded by President Franklin D. Roosevelt's controversial "court-packing plan" in the Judicial Procedures Reform Bill of 1937, which credibly threatened the Supreme Court into taking a much more

\footnotetext{
46 Anisminic, supra note 44, at 171.

47 O'Reilly v. Mackman [1983] 2 A.C. 237, 238.

48 Elliott \& Thomas, supra note 15 , at 618.

$49 \quad$ Id.

50 Kathryn A. Watts, Proposing a Place for Politics in Arbitrary and Capricious
} Review, 119 YaLe L.J. 79 (2009). 
deferential approach to the constitutionality of New Deal programs. ${ }^{51}$ As in England and Wales, judicial "abdication" 52 of control of executive action began to change in America during the next two decades, as agencies expanded their jurisdictions to include industry-wide rate regulation, ${ }^{53}$ and resorted ever more to informal notice-and-comment rule-making, after an explosion of new enabling Acts had been passed that had launched ambitious regulatory undertakings supposed to protect the environment and consumers, and promote public health and safety. ${ }^{54}$ These and other such encroachments heightened concerns that agency proceedings might give insufficient weight to the interests of all stakeholders. ${ }^{55}$ Rolling back decades of judicial acquiescence in administrative expansion, ${ }^{56}$ administrative common law made a remarkable comeback in stringent judge-made substantive and procedural checks and balances on agencies' decision-making, ${ }^{57}$ which has been described as a "revolution in administrative law." 58

The pioneer in this legal transformation was not the apex court, as in the United Kingdom; but rather, the Court of Appeals for the District of Columbia Circuit (commonly known as the "D.C. Circuit"), which reinvented itself in 1970 as "a de facto quasi-specialized administrative law court of last resort," 59 even though, strictly speaking, it is just one of the thirteen federal Courts of Appeals. In the 1970s federal judges, especially those on the D.C. Circuit, came to the view that administrative law needed "special solicitude" for consumer, environmental, and other interests that judges deemed underrepre-

51 Jennifer Bachner \& Benjamin Ginsberg, What Washington Gets Wrong:

The Unelected Officials Who Actually run the Government and Their Misconceptions about the American People 28 (2016).

52 Stephen G. Breyer, Judicial Review of Questions of Law and Policy, 38 ADMIN L. REv. 363, 395 (1986).

53 Thomas W. Merrill, Capture Theory and the Courts: 1967-1983, 72 CHI.-KENT

L. REV. 1092 (1997).

54 Keith Werhan, Principles of Administrative Law 397 (2d ed., 2014).

55 Note, Rationalizing Hard Look Review after the Fact, 122 HARV. L. ReV. 1912 (2009).

56 One way is to permit the non-delegation doctrine to descend into obscurity. See Kathryn A. Watts, Proposing a Place for Politics in Arbitrary and Capricious Review, 119 Yale L.J. 79 (2009).

57 BREYER ET AL., supra note 7, at 28.

58 Joseph Postell, Bureaucracy in America: The Administrative State's Challenge to Constitutional Government 247 (2017).

59 Christopher P. Banks, Judicial Politics in the D.C. Circuit Court xiii (1999); Harold H. Bruff, Coordinating Judicial Review in Administrative Law, 39 U.C.L.A. L. REV. 1193, 1203 (1992). 
sented in the political process. ${ }^{60}$ They were also increasingly skeptical of the traditional New Deal's assumption of administrative fidelity, apparently suspecting certain agencies of not acting in the public interest, if not indeed bribed by the very private interests and industries they were meant to regulate. ${ }^{61}$ Specialist agencies are, after all, easy targets for influence by special interest groups. They are considered vulnerable to "regulatory capture," 62 because their heads are political appointees; their work is more specialized; and they are less insulated from the legislative and electoral processes than judges. ${ }^{63}$ Although they are vetted and overseen by Congressional committees, experience has shown this to be inadequate. These shifts of judicial perception, and similar changes in the minds of citizens, precipitated an "aftershock" of administrative lawsuits, as evidenced by the four-fold increase of filings in the D.C. Circuit from 1969 to $1979 .{ }^{64}$ Most notably, the "arbitrary and capricious" standard was rigorized by the demand inter alia of an administrative record even for informal rule-making, and proof of rigorously logical analysis having been applied if agencies claim discretion. ${ }^{65}$

A deep judicial distrust of the uncontrolled regulatory state prompted harder law that exacts reasoned explanations and adequate evidence from agencies under review. ${ }^{66}$ The "lethal-sounding" ${ }^{\prime \prime 7}$ epithet "hard look" 68 was coined in

60 Cass R. Sunstein \& Adrian Vermeule, Libertarian Administrative Law, 82 U. Chi. L. Rev. 393, 394 (2015).

${ }_{61}$ Scott A. Keller, Depoliticizing Judicial Review of Agency Rulemaking, 84 WASH. L. Rev. 438 (2009).

62 Sidney A. Shapiro \& Joseph P. Tomain, Achieving Democracy: The Future of Progressive Regulation 142 (2014) ("Regulators needed information and expertise from regulated industries, and regulated firms wanted some protection and assurances against what they perceived as unwarranted competition from new entrants. Regulators in other words helped sustain the very industries and firms that they were regulating, and the regulator-regulatee relationship was susceptible to capture.")

63 Richard A. Posner, Regulation (Agencies) versus Litigation (Courts): An Analytical Framework, in Regulation vs. Litigation: Perspectives from Economics AND LAW 11, 19 (Daniel P. Kessler ed., 2011).

64 Patrick M. Garry, Judicial Review and the "Hard Look" Doctrine, 7 Nev. L.J. 168 (2006).

${ }_{65}$ Lisa Schultz Bressman, Beyond Accountability: Arbitrariness and Legitimacy in the Administrative State, 78 N.Y.U. L. Rev. 461, 476 (2003).

${ }_{66}$ See Matthew J. Warren, Active Judging: Judicial Philosophy and the Development of the Hard Look Doctrine in the D.C. Circuit, 90 Geo. L.J. 2599 (2002).

67 Denis J. Galligan, Discretionary Powers: A Legal Study of Official DisCRETION 317 (1986).

${ }_{68}$ See Harold Leventhal, Environmental Decisionmaking and the Role of the Courts, 122 U. PA. L. Rev. 514 (1974). 
$1969^{69}$ by a D.C. Circuit Judge, Harold Leventhal, in Pikes Peak Broadcasting Co. v. FCC. ${ }^{70}$ In Greater Boston Television Corp. v. FCC, ${ }^{71}$ Judge Leventhal opined, "The function of the court is to assure that the agency has given reasoned consideration to all material facts and issues"; that it can "articulate with reasonable clarity its reasons for decision," and "identify the significance of the crucial facts"; and that it will "effectuate general standards, applied without unreasonable discrimination." 72 A year later, in Citizens to Pres. Overton Park, Inc. v. Volpe ${ }^{73}$ the Supreme Court potentiated the public availability of "hard look" review, ${ }^{74}$ by holding lower reviewing courts to conducting a "substantial inquiry" and "a thorough, probing, in-depth review" to ascertain "whether the decision was based on a consideration of the relevant factors." 75 To discharge their responsibility, the courts may even "require the administrative officials who participated in the decision to give testimony explaining their action."76

The "hard look" doctrine was originally understood as a rule requiring verification that the agencies had taken a hard look at their own decisions; within a decade, the term had evolved so far as to mean that it was for the courts to take the hard look at agencies' acts. ${ }^{77}$ As Judge Patricia Wald of the D.C. Circuit noted in Nat'l Lime Ass' $n v$. EPA, "[t] impact of the urgent regulations issued under the new rulemaking provisions and the diffidence of judges in the face of highly technical regulatory schemes prompted the courts to require the agencies to develop a more complete record and a more clearly articulated rationale to facilitate review for arbitrariness and caprice"; but "[a]s these newly-required records and rationales became more routinely available, the 'hard look' taken began to appear more judicial than administrative, blurring the original meaning of that phrase." ${ }^{\prime 79}$

Judicial review of administrative action has undergone a common revival in the United Kingdom and the United States, which yet have parted company

69 Thomas O. McGarity, The Courts and the Ossification of Rulemaking: A Response to Professor Seidenfeld, 75 TEx. L. REv. 525, 527, n.5 (1997).

70 Pikes Peak Broadcasting Co. v. FCC, 422 F.2d 671, 682 (D.C. Cir. 1969).

71 Greater Boston Television Corp. v. FCC, 44 F.2d 841 (DC Cir 1970).

72 Id. at 851.

73 Citizens to Pres. Overton Park, Inc. v. Volpe, 401 U.S. 402, 415-17 (1971) [hereinafter Overton Park].

74 Garry, supra note 64, at 155 (2006).

75 Overton Park, supra note 73, at 415-16.

76 Id. at 420.

77 Sidney A. Shapiro \& Richard W. Murphy, Arbitrariness Review Made Reasonable: Structural and Conceptual Reform of the "Hard Look", 92 Notre Dame L. REV. 331, 346 (2016).

78 Nat'l Lime Ass'n v. EPA, 627 F.2d 416, 451-452 n. 126 (D.C. Cir. 1980).

79 Id., at 451-452, n. 126. 
toward their ultimate destinations. The Law Lords' expansion of the breadth of the applicability of English administrative law, together with their maintenance of a "shallow" judicial penetration at best, support an inference that they are much more receptive to review of questions of law than of fact. In contrast, the D.C. Circuit's and the American Supreme Court's "narrow" but "deep" doctrines evince the opposite. English administrative law jealously defends the supremacy of the judiciary over all matters of statutory construction, while obliging them to step back from questioning administrators' substantive policy and factual findings; whereas United States administrative law instructs the federal courts to defer to agencies' statutory-interpretive autonomy, while taking a "hard look" at their substantive factual and policy determinations. ${ }^{80}$ Administrative acts in England can be set aside only on grounds relating to illegality, perversity, or procedural impropriety. ${ }^{81}$ In America, the scope for judicial control of administrative acts is "much wider," 82 allowing courts to conduct intrusive substantive analyses of administrative behavior "beyond anything that can be done in English law." ${ }^{\prime 3}$ On the pretext that an administrative act is devoid of a "rational legal basis," American federal courts frequently go on to replace the policy judgments of agencies with their own. ${ }^{84}$ The authors of a major treatise on American administrative law, including Justice Stephen Breyer of the Supreme Court, used the following words to describe this "anomaly"85: "How odd. The American courts defer to agencies on questions of law, where courts are expert, but they conduct 'in-depth' reviews of policy, where agencies are expert. They seem to have it backwards." 86 For the legal scholar Richard Epstein, it is "[t]he great tragedy of modern administrative law." Indeed, these administrative law doctrines "have little connection" with what the relevant provisions of the Administrative Procedure Act of 1946 meant when it was first enacted..$^{88}$

80 Richard A. Epstein, Design for Liberty: Private Property, Public Administration, AND the Rule of LaW 154 (2011).

81 Council of Civil Service Unions v. Minister for the Civil Service [1985] A.C. 374, 410 [hereinafter $G C H Q]$.

82 P.S. Atiyah \& R.S. Summers, Form and Substance in Anglo-American Law: A Comparative Study of Legal Reasoning, Legal Theory, and Legal Institutions 61 (1987).

83 Id., at 62.

$84 \quad I d$.

85 Robert C. Dolehide, A Comparative "Hard Look" at Chevron: What the United Kingdom and Australia Reveal About American Administrative Law, 88 TEx. L. Rev. 1381, 1383 (2010).

86 BREYER ET AL., supra note 7, at 365.

87 Epstein, supra note 80, at 154.

88 Metzger, supra note 14, at 1311-12. 
The purpose of this study is to undertake the previously untried task of explaining from a PPT perspective, with a book-length treatment, this doctrinal antithesis ${ }^{89}$ in the administrative common law both of the Appellate Committee of the House of Lords (and the Supreme Court of the United Kingdom, its successor), ${ }^{90}$ and of the Supreme Court of the United States. ${ }^{91}$ It is argued that the antithetical doctrinal approaches adopted by the two apex courts to judicial review of administrative action can be powerfully explained by the polarization of the British and American polities along a continuum of effective "veto-gates," institutions competent to veto legislative proposals in circumstances that may force a reversion to the status quo. ${ }^{92}$ This book therefore explores the political underpinnings of this remarkable antithesis in Anglo-American administrative law; the adjective "Anglo-American" is used because this book chiefly addresses, apart from United States federal law, the legal system of England and Wales, which constitutes a distinct legal jurisdiction of the United Kingdom, different and independent from those of Scotland and Northern Ireland despite the historical event of union. ${ }^{93}$ Note, however, that England has no political institutions of its own, like, say, the Scottish Parliament, and thus only British or United Kingdom political institutions will be referred to in this book. ${ }^{94}$

The rest of this chapter is organized as follows. The second Section sets out the methodological considerations. It explains the "most-similar-cases"

89 See Eric C. Ip, Doctrinal Antithesis in Anglo-American Administrative Law, 22 Sup. Ct. Econ. Rev. 147 (2015).

90 Positive political theory or rational choice theory is underdeveloped in the study of British government and laws. See Keith Dowding, Rational Choice and British Politics, in Oxford Handbook of British Politics 75 (Andrew Gamble et al. eds., 2009).

91 This book is not concerned with how the administrative law decisions of the Anglo-American apex courts were actually enforced or implemented. PPT-informed empirical studies have been dedicated to this question in the American context. See Thomas J. Miles \& Cass R. Sunstein, The Real World of Arbitrariness Review, 75 U. Chr. L. Rev. 761 (2008); Thomas J. Miles \& Cass R. Sunstein, Do Judges Make Regulatory Policy? An Empirical Investigation of Chevron, 73 U. CHI. L. Rev. 823 (2006).

92 Stephan Haggard, The Politics of Corporate and Financial Restructuring: A Comparison of Korea, Thailand, and Indonesia, in Resolution of Financial Distress: An International Perspective on the Design of Bankruptcy Laws 262, n 1 (Stijn Claessens et al. eds., 2001).

93 Each British jurisdiction has a separate judiciary. Particularly, Scotland is a mixed civil law-common law jurisdiction. See Andrew Le Sueur \& Evelyn Ellis, Constitutional Fundamentals, in Oxford Principles of English Law: English Public Law 12 (David Feldman ed., 2d ed. 2009).

94 AтזYAh \& Summers, supra note 62, at xiii. 
method chosen to study divergent cases of the administrative law of the United Kingdom and the United States; why this book focuses on the administrative jurisprudence mostly at the Supreme Court or final appellate level, rather than covering other levels of the Anglo-American judiciaries; and the reasons for taking judicial doctrine seriously even in an interdisciplinary inquiry like the present project. The third and last Section provides the reader with a roadmap of how the rest of this book is organized.

\section{METHODOLOGICAL CONSIDERATIONS}

This is one of the very first books of the twenty-first century to study the diametrically opposite approaches to the judicial review of administrative decisions taken by English and American courts since the Second World War. ${ }^{95}$ The findings, which stem from the two most influential common law jurisdictions of the world, will have applications to other members of the common law world. This book breaks new ground in using the insights of PPT to explain the institutional and strategic foundations of Anglo-American comparative administrative law. ${ }^{96}$ The New Zealand comparative administrative law scholar Michael Taggart noticed in 1997 that "[i]n contrast to the popularity of Constitution-watching from afar, American administrative law is a closed book to most Commonwealth administrative lawyers." ${ }^{97}$ Little has changed since then. Filling a gap in the existing literature, this book retraces the political origins of the divergence back beyond its immediate cause: the three remarkable judgments delivered by the apex courts of the United Kingdom and the United States between 1983 and 1984, which permanently redefined both judicial traditions of substantive review: Council of Civil Servs. Unions $v$. Minister for the Civil Servs., ${ }^{98}$ commonly known as the "GCHQ case"; Motor Vehicle Mfrs. Ass'n v. State Farm Mut. Auto. Ins. Co.; ${ }^{99}$ and Chevron U.S.A.,

\footnotetext{
95 Peter Cane, Controlling Administrative Power: An Historical COMPARISON (2016).

96 Paul Craig, Comparative Administrative Law and Political Structure, 37 OXFoRD J. Legal Stud. 946, 946 (2017) ("Study of comparative administrative law reveals commonality and difference between the systems studied. That is axiomatic and self-evident. The depth of the resulting similarities and divergences may be difficult to estimate, the explanation for them even more so").

97 Michael Taggart, The Province of Administrative Law Determined?, in THE Province of Administrative Law 1, 18 (Michael Taggart ed., 1997).

98 GCHQ, supra note 81.

99 Motor Vehicle Mfrs. Ass'n v. State Farm Mut. Auto. Ins. Co., 463 U.S. 29, 43, 52 (1983).
} 
Inc. v. Natural Res. Def. Council, Inc., ${ }^{100}$ "the most cited case in modern public law." 101 This will help bridge the scholarly gap between doctrinal analysis of administrative law and political science studies of the regulatory state, stimulating further interdisciplinary inquiry into the interaction of courts and bureaucrats in a wide variety of national settings.

The "most-similar-cases" research design is applied to conducting the inference-oriented and controlled administrative common law comparison between the Supreme Courts of the United Kingdom and the United States. The logic of this method is to compare and contrast two or more cases which share overall similarities on all variables not critical to the research question; yet exhibit variance in the values of the independent and dependent variables. To control variables peripheral to the investigation, the "most-similar-cases" method "isolates" the significance of variance on the key independent variable in deciding the variance on the dependent variable. This addresses the undesirability or even impossibility of statistical or experimental control in a given study. ${ }^{102}$ In comparative studies, two countries that are similar in the gamut of ways but the one variable that is being examined are chosen so that any effects can be reliably traced back to the single isolated difference. ${ }^{103}$ A careful small- $n$ analysis of "most-similar-cases" may therefore give rise to causal inferences applicable beyond these cases. ${ }^{104}$

In a landmark 2003 study of comparative constitutional judicial review, Tom Ginsburg investigated the political conditions conducive to the empowerment of constitutional courts, using Taiwan, South Korea and Mongolia - three nascent Asian democracies - as case studies ${ }^{105}$ grounded in "most-similar-cases" logic. ${ }^{106}$ All three shared important similarities of geography, culture and history, yet differed in the fate of judicial review (the dependent variable). What differed across them was the degree of electoral

100 Chevron U.S.A., Inc. v. Natural Res. Def. Council, Inc., 467 U.S. 837, 844 (1984).

101 Thomas J. Miles \& Cass R. Sunstein, Do Judges Make Regulatory Policy? An Empirical Investigation of Chevron, 73 U. CHI. L. REv. 823, 823 (2006).

102 Ran Hirschl, On the Blurred Methodological Matrix of Comparative Constitutional Law, in The Migration of Constitutional Ideas 39, 48 (Sujit Choudhry ed., 2006).

103 Katerina Linos, Methodological Guidance: How to Select and Develop Comparative International Law Case Studies, in Comparative International Law 35, 45 (Anthea Roberts et al. eds., 2018).

104 Ran Hirschl, Comparative Matters: The Renaissance of Comparative Constitutional Law 193, 244 (2014).

105 See Tom Ginsburg, Judicial Review in New Democracies: Constitutional Courts in Asian CAses (2003).

106 HirsCHL, supra note 104, at 249. 
uncertainty (the independent variable). Ginsburg inferred that the more uncertain the electoral futures are, the likelier the incumbent regime will opt to empower the judiciary as an insurance strategy against succeeding opponents; concluding that "neither culture nor history is as important as [political] structure in determining outcomes [of judicial empowerment]." ${ }^{107}$ More recently, in 2016, Julio Ríos-Figueroa deployed "most similar" design to study the constitutional jurisprudence of the use of force in Colombia, Peru, and Mexico. ${ }^{108} \mathrm{He}$ argued that no matter how similar these countries were in variables that might induce courts to regulate the use of force in internal security crises or competitive elections, they differed in those variables, e.g. accessibility to the constitutional court, which affect the role courts play in national armed conflicts. ${ }^{109}$

The United Kingdom and the United States are often paired in studies of comparative law, comparative politics, and comparative economics as "most similar systems," as they share a common language, the common law tradition, and popular culture, and are "wealthy, democratic, and internationally-engaged states," both of which are veto-wielding members of the United Nations Security Council. ${ }^{110}$ Britain and America, therefore, furnish a natural experiment, after the "most-similar-cases" logic, upon the dynamics of administrative common law. English and American law are representative of contrasting approaches despite being embedded in Anglophone liberal democracies and common law traditions. ${ }^{111}$ It follows that if English and American courts present a stark variation on the dependent variable by taking opposite approaches to the legal regulation of the administrative state, then the researcher may set aside background variables like language, culture, prosperity, commitment to liberal democratic values, and even the common law as plausible causes of their divergence. This dispenses with the need to account for radically different national contexts, as is typical of cross-country studies. ${ }^{112}$ The contrast of English and American administrative common law on questions of statutory interpretation and policy offers a precious opportunity for an in-depth investigation of the political conditions for doctrinal antitheses.

107 Ginsburg, supra note 105, at 261.

108 Julio Ríos-Figueroa, Constitutional Courts as Mediators: Armed Conflict, Civil-Military Relations, and the Rule of Law in Latin America (2016).

109 Id. at 14.

110 Ashley S. Deeks, Intelligence Communities and International Law: A Comparative Approach, in Comparative International Law 251, 253 (Anthea Roberts et al. eds., 2018).

111 See Nadia E. Nedzel \& Nicholas Capaldi, The Anglo-American Conception OF THE RULE OF LAW 151-153 (2019).

112 See Markus Freitag \& Adrian Vatter, Patterns of Democracy: A Subnational Analysis of the German Lander, 44(4) Acta Politica 410, 411 (2009). 
This book focuses primarily, but not exclusively, on the apex judicial level for at least two reasons. First, the exclusion of lower court decisions is necessary to keep the study manageable. There is only one court of last resort in England, whereas in the United States there are many courts of last resort, one for each state, plus the federal Supreme Court. ${ }^{113}$ In brief, the federal courts are a minuscule part of the American judiciary, as there are many more state courts than federal ones, and state judges have heavier caseloads than their federal colleagues. ${ }^{114}$ That said, the United States has thirteen federal Courts of Appeals, ${ }^{115}$ compared to only one Court of Appeal of England and Wales. Moreover, these Anglo-American courts do not have identical jurisdictions despite substantial overlap in legal domains like admiralty, contracts, torts, criminal law, intellectual property and bankruptcy. ${ }^{116}$ England's is a "disproportionately smaller" system than the American, above all, in terms of either personnel or activity; which, as eminent scholar-judge Richard Posner concedes, makes overall comparisons difficult. ${ }^{117}$

Second, common law apex courts are highly influential and worthy of dedicated studies, as they not only decide cases at bar, but also create sweeping doctrines at times, destined to govern similar cases across the whole system of law. This is why the few disputes that really reach common law apex courts are likely to be academically interesting and complicated. ${ }^{118}$ The Supreme Court of the United Kingdom, formerly known as the Appellate Committee of the House of Lords, which used to be formally a part of Parliament, exercises appellate powers over criminal and civil cases of England and Wales and Northern Ireland, and civil cases of Scotland. ${ }^{119}$ The Court's twelve judges, including the President, typically sit in smaller panels of five. ${ }^{120}$ They are appointed by the Monarch in accordance with the nomination of an inde-

113 ATIYAH \& Summers, supra note 62, at 267.

114 Richard A. Posner, LaW and Legal Theory in the UK and USA 81 (1996).

115 These include the Courts of Appeal for the D.C. Circuit, the First Circuit, the Second Circuit, the Third Circuit, the Fourth Circuit, the Fifth Circuit, the Sixth Circuit, the Seventh Circuit, the Eighth Circuit, the Ninth Circuit, the Tenth Circuit, the Eleventh Circuit, and the Federal Circuit.

116 Posner, supra note 114, at 85.

117 Id. at 83.

118 David Robertson, The Judge as Political Theorist: Contemporary Constitutional Review 5 (2010).

119 This book focuses exclusively on the Appellate Committee of the House of Lords or the Supreme Court of the United Kingdom acting in its capacity as the final court of appeal of England and Wales, rather than that of Northern Ireland and Scotland.

120 Cornelis Hendrik (Remco) van Rhee \& Yulin Fu, Introduction, in Supreme Courts in Transition in China and the West Adjudication at the Service of Public Goals 6 (Cornelis Hendrik (Remco) van Rhee \& Yulin Fu eds., 2017). 
pendent and non-partisan Judicial Appointments Commission; the incumbent Government, through the Lord Chancellor, may exercise a veto against the nomination under narrowly defined circumstances. ${ }^{121}$ The statutory retirement age of Justices is currently fixed at 70 years old. ${ }^{122}$ By the time they are appointed, Justices typically have only a few years of service remaining. ${ }^{123}$ Judgments of the Court are considered authoritative, to varying degrees, by the courts of some fifty members of the Commonwealth of Nations, ${ }^{124}$ by the several British Overseas Territories, remnants of the British Empire, ${ }^{125}$ and even by certain non-Commonwealth jurisdictions like the Hong Kong Special Administrative Region of the People's Republic of China. ${ }^{126}$ The percentage of public law cases in its docket rocketed from 13 percent in 1970-1972 to 40 percent in 2009-2013. ${ }^{127}$ Paradoxically, political scientists who are interested in British politics have seldom studied the Supreme Court, ${ }^{128}$ a scholarly loophole that this book will help to close.

Unlike its British counterpart, the nine-member American Supreme Court is a collegial one in which all judges take part in all judgments. Justices of the Supreme Court are appointed by the President of the United States "by

121 Constitutional Reform Act $2005 \S \S 25-31$; Sched. 8.

122 Judicial Pensions and Retirement Act 1993 § 26(1).

123 Philip Norton, The Judiciary, in Politics UK 444-445 (Bill Jones \& Philip Norton eds., 8th ed. 2014).

124 See Michael Kirby, Australia and New Zealand, in The Judicial House of Lords: 1876-2009 339 (Louis Blom-Cooper et al. eds., 2009); Robert J. Sharpe, Canada, in The Judicial House of Lords: 1876-2009 351 (Louis Blom-Cooper et al. eds., 2009); Arthur Chaskalson, South Africa, in The Judicial House of Lords: 1876-2009 360 (Louis Blom-Cooper et al. eds., 2009); Adarsh Sein Anand, India, 367; Fred Phillips, Reflections from the New Commonwealth, in The Judicial House of LORDS: 1876-2009 376 (Louis Blom-Cooper et al. eds., 2009).

125 See Ian Hendry \& Susan Dickson, British Overseas Territories Law (2d ed. 2018).

126 Solicitor (24/07) v. Law Soc'y of Hong Kong, (2008) 11 H.K.C.F.A.R. 117, at 133:

Before 1 July 1997, decisions of the House of Lords stood in a similar position to decisions of the Privy Council on non-Hong Kong appeals. Although they were only persuasive, their authority was very great unless the decision was in a field where local circumstances made it appropriate for Hong Kong to develop along different lines. The House of Lords and the Privy Council essentially share a common membership. Unless local circumstances were material, the Privy Council on an appeal from Hong Kong was unlikely to diverge from a decision its members had reached in a different capacity in the House of Lords.

127 Alan Paterson, Final Judgment: The Last Law Lords and the Supreme COURT 17 (2013).

128 Keith Ewing, Judiciary, in The Oxford Handbook of British Politics 262, 263 (Matthew Flinders et al. eds., 2011). 
and with the Advice and Consent of the Senate"129 There is no mandatory retirement age for Justices. This Court is arguably the world's single most influential judicial body, in the sense that its public law jurisprudence harking back to Marbury v. Madison ${ }^{130}$ has influenced not only the legal systems of the American states with its judicial review and binding precedent, but also the legal systems, both common and civil, of many other countries whose apex courts have often looked to it for guidance. ${ }^{131}$ Judicial review of administrative acts is a substantial portion of its work: no less than 22 percent of all decisions of that Court between 1946 and 2012 involved disputes originating from federal agency proceedings. ${ }^{132}$

The rationale for focusing on judicial doctrine herein is that it is "the currency of the law," "133 the summation of legal rules and standards articulated in particular judgments, ${ }^{134}$ making up the core of judicial acts. ${ }^{135}$ Doctrines can be conceptualized as the "routine challenge and defense structures" accompanying particular fact patterns. ${ }^{136}$ On the one hand, clear judicial doctrines macro-manage judges' future conduct, ${ }^{137}$ and minimize the discretion of capricious agencies. ${ }^{138}$ On the other, as decision instruments they equip judges with stratagems qua legal principles for reaching preferred legal outcomes. ${ }^{139}$ Doctrines are economical as they relieve judges of the necessity to reason from scratch, conserving precious time and mental energy in the strenuous task of crafting new rules and standards that set the terms for practical dispute resolution well into the future. ${ }^{140}$ Doctrines also let prospective litigants predict what might happen in their cases if they proceed to litigation, which in turn influences future doctrines. ${ }^{141}$ Legal scholars have studied doctrine from a normative perspective, but have yet to give proper attention to its practical utility.

\footnotetext{
129 U.S. Const. art. II, § 2, cl. 2.

130 Marbury v. Madison, 5 U.S. 137 (1803).

131 Simona Grossi, The U.S. Supreme Court and the Modern Common Law ApproACH 1-2 (2015).

132 Ryan C. Black et al., U.S. Supreme Court Opinions and Their Audiences 83 (2016).

133 Emerson H. Tiller \& Frank B. Cross, What is Legal Doctrine?, 100 Nw. U. L. REV. 517, 517 (2006).

134 Id.

135 RoBERTSON, supra note 118 , at 21.

136 Emerson H. Tiller, The "Law" and Economics of Judicial Decision-Making: A Positive Political Theory, in The Oxford Handbook of Law And Economics Volume I: Methodology and Concepts 221, 226 (Francesco Parisi ed., 2017).

137 Id. at 227

138 BLACK ET AL., supra note 132, at 87.

139 Tiller, supra note 136, at 242.

140 Tiller \& Cross, supra note 133, at 517.

141 Elliott \& Robert Thomas, supra note 15, at 597.
} 
Oddly, many of the same social scientists who have conducted significant explanatory or descriptive research into law and courts, uncritically assume that legal doctrine is irrelevant. ${ }^{142}$ An overstatement of politics' importance to judging either unduly downplays the corpus of detailed justificatory arguments that judges craft, or cynically denies it as a kind of intentional conspiracy to obscure the truth. ${ }^{143}$ Neither is close to reality. Most appellate decisions in the United States, for instance, are unanimous, and disagreements between judges as evidenced by dissenting judgments are not always neatly distributed on an ideological scale. ${ }^{144}$ Correlations with ideology do not logically entail that judgments are driven by nothing but the personal ideological preferences of judges. ${ }^{145}$ Empirical research supports the proposition that "law matters" in how judges make decisions, even though extralegal considerations may from time to time inform their knowledge about the demands of the law. ${ }^{146}$ Even less appreciated is how doctrine influences politics. ${ }^{147}$ Administrative agencies might ex ante adapt their behavior to the Supreme Court's administrative common law in anticipation of activist judicial review. ${ }^{148}$ Groundbreaking empirical or behavioral studies of law and courts will not be possible until first the phenomenon is fully fathomed. ${ }^{149}$ By taking judicial doctrine seriously, this book is bound to narrow the chasm between jurists and social scientists, who have historically produced separate and contending literatures on the same topic of judicial decision making. ${ }^{150}$ Words - judicial words - matter. They

\footnotetext{
142 RoBertson, supra note 118, at 24.

143 Keith J. Bybee, Paying Attention to What Judges Say: New Directions in the Study of Judicial Decision Making, 8 Annu. Rev. Law Soc. Scr. 69, 81 (2012).

144 Farber, supra note 18, at 197.

145 Id. at 196.

146 Judicial independence "enables judges to uphold the law as they are acculturated
} to do, free from electoral intimidation to do otherwise"; "liberates judges to afford litigants a full and fair hearing, unencumbered by pressure to reach a particular result by any means necessary"; and "creates a buffer that permits judges to set the public mood aside and dispense justice on the basis of case specific facts as applied to operative lawfacts that judges are better situated than voters to know." Charles Gardner Geyh, Who is to Judge? The Perennial Debate Over Whether to Elect or Appoint AMERICA's Judges 165 (2019).

147 Tiller \& Cross, supra note 133, at 518.

148 Ronald J. Gilson \& Alan Schwartz, Constraints on Private Benefits of Control: Ex Ante Control Mechanisms versus Ex Post Transaction Review, 169 J. Inst. \& THEORETiCAL ECon. 160, 167 (2013).

149 Jan M. Smits, What Is Legal Doctrine? On the Aims and Methods of Legal-Dogmatic Research, in Rethinking Legal Scholarship: A Transatlantic Dialogue 207, 227 (Rob van Gestel et al. eds., 2017).

150 Bybee, supra note 143, at 71. 
shape our political lives. ${ }^{151}$ And the PPT of law is an extremely useful tool to advance our understanding of how politics and judicial doctrine shape each other.

\section{ORGANIZATION OF CHAPTERS}

This book is organized as follows. ${ }^{152}$ Chapter 2: A Veto-gate Theory of Administrative Common Law, brings out of the relevant PPT literature an explanatory framework, the cynosure of which remains the veto-gate. It is theorized that the smaller the number of effective veto-gates in a political system, the more likely judicial review will focus more on questions of law and less on questions of factfinding and discretion; and vice versa. This chapter argues that the underlying causal mechanism producing these results consists of legislators' aggregate preference to control agency costs versus apex court judges' aggregate preference to conserve judicial authority and resources. This explanatory framework focuses exclusively on questions of common law doctrinal design. It can illuminate the interplay between the legislative process, the regulatory state, and the courts, and is also applicable to other common law jurisdictions. Consequently, it is unconcerned with the normative justifiability of particular administrative law principles, nor does it presume that the courts of England and America have in practice adhered unswervingly to their stark differences in doctrine.

Chapter 3: Law and the Regulatory State, evidences that both the United Kingdom and the United States witnessed the expansion of judicial review of administrative acts proportional to the expansion of the regulatory state after the Second World War, that English and American administrative common law once had many similarities, both historically and doctrinally, up until the second half of the twentieth century. In both countries, the courts were supposed to conserve final authority to pronounce on all questions of statutory interpretation into their own hands, yet accord substantial deference to administrative decision-makers in their factfinding and discretionary activities. This observation establishes that the antithesis that ensued cannot be wholly or chiefly ascribed to the differences between the institutional design and appointment methods of the two Supreme Courts being studied. This result justifies setting aside variables such as doctrinal history, the growth of the

\footnotetext{
151 George Lakoff, The Political Mind: A Cognitive Scientist's Guide to Your Brain and its Politics 241 (2009).

152 Many of the ideas contained in this book are derived, albeit in heavily modified form, from the author's earlier work in Ip, supra note 89, and in Eric C. Ip, Taking a "Hard Look" at "Irrationality": Substantive Review of Administrative Discretion in the US and UK Supreme Courts, 34 Oxford J. Legal Stud. 481 (2014).
} 
administrative and regulatory state, and political culture as relatively unimportant in making sense of the Anglo-American administrative common law antithesis.

Chapter 4: Judicial Review of Administrative Statutory Interpretation evinces how the polarization of both polities along the dimension of the number of effective veto-gates within the lawmaking process is key to explaining why antithesis took over English and American administrative common law, their historical similarities notwithstanding. ${ }^{153}$ Legislation may be enforced solely by courts, or it may be enforced only at the retail level through individualized enforcement actions. But in the modern era, legislators delegate a good deal of the policymaking process to agencies. The question of why legislators do this "requires little discussion in terms of parliamentary systems, where the executive and legislature usually have identical preferences," but is more complicated in presidential systems where the executive and legislative branches are co-principals who may have different preferences. ${ }^{154}$ The absence of multiple effective veto-gates in the United Kingdom enables House of Commons majorities, acting in concert with the Cabinets they control, to delegate the least possible de facto lawmaking authority to an autonomous administrative state. The Supreme Court of the United Kingdom was thus able to assert that the meaning of statutory provisions was for the courts to determine with finality as matters of law. ${ }^{155}$ In stark contrast, the profusion of effective veto-gates in the United States in the late twentieth century has pushed Congress toward delegating vast lawmaking powers to influential administrators, even as they have undermined the efficacy of its oversight procedures. In the United States a great many federal statutes delegate lawmaking powers to federal agencies without explicit accompanying legal standards for their exercise. ${ }^{156}$ The Supreme Court's doctrinal encoding of judicial deference to agency statutory interpretations in cases like Chevron, as required by such a polarized polity, helped preempt the federal legislative process from grinding to a halt. Simultaneously, the oversight vacuum left by gridlock has made possible aggressive judicial review of agency discretionary decision-making and findings of fact.

Chapter 5: Judicial Review of Factfinding and Discretion argues that the United Kingdom's scarcity of effective veto-gates explains Parliament's dele-

153 Matthew D. McCubbins, Legislative Process and the Mirroring Principle, in Handbook of New Institutional Economics 132 (Claude Menard \& Mary M. Shirley eds., 2005).

154 Farber, supra note 18, at 194.

155 Paul Tucker, Unelected Power: The Quest for Legitimacy in Central Banking and the Regulatory State 361 (2018).

156 AтіYAH \& Summers, supra note 62, at 63. 
gation of scant statutory construction powers to the administrative authorities, and to conserve oversight powers in the hands of the House of Commons majority, whose leaders control the Government. This has nudged the Supreme Court to defer to Parliament's and the Government's primary roles in oversight. Concretely put, it has compelled the Law Lords to fashion doctrines that disregard administrative statutory interpretation but give a broad margin of deference to the Commons majority's primacy in overseeing administrative officials' findings of fact. The multiplicity of veto-gates in the United States, by contrast, compelled Congress to delegate considerable powers of statutory construction to administrative agencies, while it weakened the oversight capacity of the Congressional majority. Both developments persuaded the Supreme Court to encode in its administrative jurisprudence deference to agencies' statutory interpretations but not their evidentiary findings. Therefore, administrative common law in England, under the rubric of "irrationality review," continues to refrain from scrutinizing the substance of decisions except in the most unusual circumstances, while its counterpart in America is apt to conduct "arbitrariness reviews" by taking a "hard look" at regulatory agencies' determinations and factual findings, even the highly technical ones. Judicial review of agency decisions in the United States is in many respects more exacting than review by the English judiciary, which still exhibits a marked reluctance to substitute their own policy and ideological preferences so long as standards of legality, reasonableness and natural justice are met. ${ }^{157}$

Chapter 6: Closing Remarks summarizes the main findings by applying the Veto-gate Theory of Administrative Common Law to correlate long-term changes in the polities' number of veto-gates with the two Supreme Courts' contrasting doctrinal edifices on questions of legal interpretation versus policy. It reviews the question of why the United Kingdom and the United States Supreme Courts have chosen such divergent approaches to judicial review of agency action, despite comparable background variables having remained constant. It theorizes how the polarization of Britain and America on the measure of veto-gates is key to explaining why an antithesis emerged between the two

157 TUCKER, supra note 155, at 360. The due process clauses of the Constitution of the United States, together with the Administrative Procedure Act, provide for various participatory guarantees in administrative adjudication and rulemaking that are elaborate and codified, as opposed to the rudimentary, judicially developed, principles of natural justice in England and Wales. See Marco D'Alberti, Transformations of Administrative Law: Italy from a Comparative Perspective, in Comparative Administrative Law 102, 112 (Susan Rose-Ackerman et al. eds., 2d ed. 2017); Frederick F. Shauer, English Natural Justice and American Due Process: An Analytical Comparison, 18 WM. \& Mary L. Rev. 47 (1976). A political explanation of the convergences and divergences of American due process and English natural justice is beyond the scope of this book. 
great common law flagships, their political, economic and social similarities notwithstanding. This chapter closes the book with concluding remarks on the stable state of administrative common law doctrines on both sides of the Atlantic for the past four decades, ${ }^{158}$ and forecasts their future in the light of recent political developments that seemed to threaten the status quo, such as the introduction of a proposed Separation of Powers Restoration Act into the American Congress in 2016, which sought to abolish Chevron deference, and the British Supreme Court's landmark decision in $R$ (on the application of Miller) v. The Prime Minister, ${ }^{159}$ which apparently abandoned Wednesbury irrationality for a more stringent standard in quashing Prime Minister Boris Johnson's advice to the Queen in Council to prorogue Parliament shortly before the then-Brexit deadline.

158 Jeffrey S. Lubbers, Administrative Law in the United States, in Comparative Administrative Law: Administrative Law in the European Union, Its Member States and the United States 357, 408 (René Seerden ed., 2018).

$159 R$ (on the application of Miller) $v$. The Prime Minister [2019] U.K.S.C. 41. 